\title{
Growth and production performance of carps in shaded pond in Barisal, Bangladesh
}

\author{
R. J. Rumpa ${ }^{1}$, M. M. Haque ${ }^{1^{*}}$, M. M. Alam ${ }^{2}$ and S. M. Rahamatullah ${ }^{1}$ \\ ${ }^{1}$ Department of aquaculture, Bangladesh Agricultural University, Mymensingh-2202, Bangladesh \\ ${ }^{2}$ Department of Fisheries Technology, Bangladesh Agricultural University, Mymensingh-2202, Bangladesh \\ *E-mail: mmhaque1974@yahoo.com
}

\begin{abstract}
The shaded nature of ponds in Barisal region constrained the pond polyculture. The present study was conducted with such shaded ponds to evaluate the growth and production performance of different carp species including rohu (Labeo rohita), catla (Catla catla), mrigal (Cirrhinus cirrhosus) and common carp (Cyprinus carpio) in polyculture system. In this experiment, polyculture of carps at similar densities were conducted in two different types of shaded ponds selecting nine ponds at Dinar village in Charkawa Union of Barisal Sadar sub-district. Out of 9 ponds, 5 were heavily shaded ponds (HSP) and 4 were moderately shaded ponds (MSP) considered as $T_{1}$ and $T_{2}$, respectively. The average area of HSP and MSP was $0.03 \pm 0.01$ and $0.07 \pm 0.03$ ha, respectively which were experimented for a period of 180 days from July to December 2013. Carps were stocked at the rate of $14820 /$ ha with the ratio of rohu, catla, mrigal and common carp - 2:1:2:1. Carps were fed with supplementary feed of the mixture of rice bran, wheat bran and mustard oilcake at the rate of $10 \%$ body weight for first 3 months and $5 \%$ body weight for last 3 months. The water quality parameters such as temperature, dissolved oxygen, $\mathrm{pH}$, nitrite and ammonia were recorded. The highest weight gain was found in common carp $(467.00 \pm 0.00 \mathrm{~g})$ in $\mathrm{T}_{1}$ and lowest weight gained in mrigal $(172.46 \pm 26.80 \mathrm{~g})$ in $\mathrm{T}_{1}$. Apart from common carp, the individual growth and production of other species was higher in MSP compared to HSP. The higher production was obtained in $\mathrm{T}_{2}(2122.92 \pm 333.60 \mathrm{~kg} / \mathrm{ha} / \mathrm{year})$ compared to $\mathrm{T}_{1}$ (1547.79 $\pm 132.94 \mathrm{~kg} / \mathrm{ha} /$ year).
\end{abstract}

Keyword: Carp polyculture, Heavily shaded ponds, Moderately shaded ponds, Barisal

\section{Introduction}

Bangladesh is a country blessed with vast fisheries resources including rivers, flood plains, lakes, ponds, ox-bow lakes, etc. which are full of 260 different fish species (DoF, 2014). The total annual fish production in Bangladesh was estimated at 3.41 million MT in 2012-13 fiscal year, of which 1.86 million MT (54.54\%) were obtained from inland aquaculture (DoF, 2014). The production of fish per hectare in Bangladesh is much lower than other fish producing countries of the world. This is due to the lack of proper knowledge on the scientific fish culture and management practices. Pond fish culture is the main aquaculture system in Bangladesh contributing to the bulk of production. Among different technologies of fish culture, pond polyculture is one of the most important culture techniques.

Polyculture is the practice of culturing more than one species of aquatic organism in the same pond. Polyculture gives higher production than monoculture in extensive systems because more available natural food is utilized by different fish species efficiently (Wahab et al., 2001). Polyculture may produce expected results if fish with different feeding habits are stocked in proper ratio and combination (Halver, 1984). In Asian polyculture, a wide variety of fish species are cultured of which rohu (Labeo rohita), catla (Catla catla) and mrigal (Cirrhinus cirrhosus) are very popular (Rahman et al., 2006). The farmers prefer to stock Common carp as a bottom feeder instead of mrigal because common carp grows faster than mrigal and the overall production is higher when combined with rohu and catla in polyculture ponds (Wahab et al., 2002). Polyculture is more productive, capital intensive and profitable activity compared to other culture systems (Dev, 2009).

Barisal district is a part of the south-central region of Bangladesh, located on the northern shore of the Bay of Bengal, which was developed by the alluvial flow of the Kirtankhola River. The livelihoods of a considerable proportion of rural people in this area depend entirely on fishing in inland open water bodies (mainly rivers and canals) and the sea, and poverty levels are particularly high (Haque et al., 2015). Rural households in Barisal region have perennial ponds which were mainly excavated as borrow pits in order 
to raise the level of homesteads to avoid flooding (Rahman et al., 1992). Availability of ponds in this area has the great potentiality of fish production applying the principle of polyculture system that generates more fish production through proper food utilization in different pond levels. Maximum pond in the rural areas become unused and are shaded by trees that can be brought under culture system, preferably polyculture system, by different native carps that will increase fish production as well as develop the economic condition of the country. The shortage of fish in the country increased day by day due to increasing population density and decreased in natural fish production. In order to meet up the shortage of fish and improving the socio economic conditions, it is essential to increase the pond fish production through adopting technology by the fish farmers in Bangladesh. The study was done in shaded ponds for carp polyculture which is an important factor for the promotion of aquaculture in Barisal district. Considering above facts, the present study was carried out to effects of stocking density on the growth performance and production of carps and to recommend suitable species for polyculture in shaded ponds in selected areas of Bangladesh.

\section{Materials and Methods}

\section{Study area}

The pond dykes in Barisal is full of trees which create shadow and reduced sunlight penetration which negatively impacts on fish culture (Haque et al., 2015). Therefore, the study was done in shaded ponds for carp polyculture which is an important factor for the promotion of aquaculture in under Charkawa Union of Barisal Sadar, in Barisal district (Fig. 1).

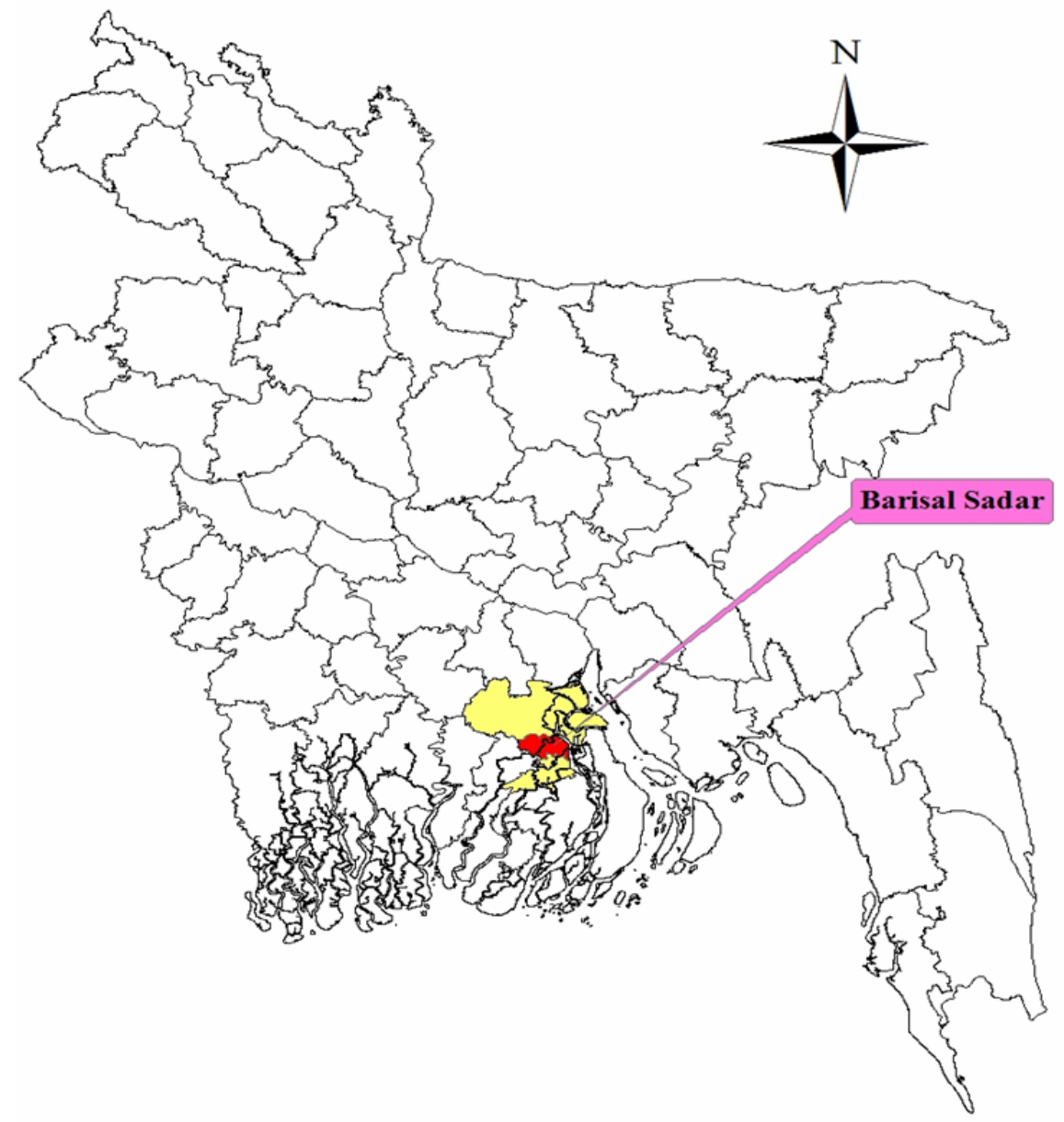

Fig. 1. Map of Bangladesh showing the study area in Barisal district 


\section{Experimental design}

For the present study, nine ponds were selected of which five were heavily shaded ponds (HSP) $T_{1}$ including P1, P2, P3, P3, P4, P5 and remaining four moderately shaded ponds (MSP) $T_{2}$ including P6, P7, P8 and P9, each pond depth ranged from 2-3 $\mathrm{m}$. The average area of HSP and MSP was $0.03 \pm 0.01$ ha and $0.07 \pm 0.03 \mathrm{ha}$, respectively. Before stocking of fish, ponds were prepared adequately by removing aquatic vegetation, unwanted and predatory species and finally treated with lime at the rate of $247 \mathrm{~kg} / \mathrm{ha}$. Carps were stocked both in HSP and MSP at the rate of 14,820/ha of rohu (Labeo rohita), catla (Catla catla), mrigal (Cirrhinus cirrhosus) and common carp (Cyprinus carpio) at the ratio of 2:1:2:1. The stocking density was similar in both HSP and MSP. Carps were fed with supplementary feed of the mixture of rice bran, wheat bran and mustard oilcake at the rate of $10 \%$ body weight for first 3 months and $5 \%$ body weight for last 3 months. To enhance the growth of natural food for the carps, fertilization was done with urea $(400 \mathrm{~kg} / \mathrm{ha})$ and TSP $(200 \mathrm{~kg} / \mathrm{ha})$ once a month. During the months of November and December, lime and salt was used at the rate of $247 \mathrm{~kg} / \mathrm{ha}$ to improve water quality.

\section{Water quality parameters}

Water quality parameters of the experimental ponds were recorded throughout the study period. The water temperature $\left({ }^{\circ} \mathrm{C}\right)$, dissolve oxygen $(\mathrm{ppm})$ and hydrogen ion concentration $(\mathrm{pH})$, ammonia $\left(\mathrm{NH}_{3}\right)$ and Nitrite $\left(\mathrm{NO}_{2}\right)$ were monitored at the beginning and end of the experiment by using proper instrument.

\section{Estimation of growth performance}

Sampling was done monthly from each pond by cast net and the weight of fish was recorded by using electric balance (Model: HKD-620AS-LED). After harvesting of fishes final weight were recorded and following parameters were used to evaluate the growth and production of the fishes.

Mean length gain $(\mathrm{cm})=$ Mean final length $(\mathrm{cm})-$ Mean initial length $(\mathrm{cm})$

Mean weight gain $(\mathrm{g})=$ Mean final weight $(\mathrm{g})-$ Mean initial weight $(\mathrm{g})$

Specific growth rate $(\mathrm{SGR} \%)=\frac{\log _{e} W_{2}-\log _{e} W_{1}}{T_{2}-T_{1}} \times 100$

Here, $W_{2}=$ the final live body weight $(\mathrm{g})$ at time $T_{2}$ day

$\mathrm{W}_{1}=$ the initial live body weight $(\mathrm{g})$ at time $\mathrm{T}_{1}$ day

$\mathrm{T}_{2}=$ time duration at the end of the experiment

$\mathrm{T}_{1}=$ initial time of the experiment (day).

Fish production $=$ No. of fish harvested $\times$ final average weight

\section{Data analysis}

The recorded data were entered into the spreadsheet in MS Excel 2010 and then summarized properly before statistical analysis. After entering the data, the descriptive statistical analyses were done by MS Excel. The inferential T-test was carried out using SPSS (Statistical Package for Social Sciences) version 16.

\section{Results}

\section{Length gain}

Statistically, there were no significant differences $(p>0.05)$ of length gain in rohu, catla, mrigal and common carp between HSP and MSP. However relatively, length gain $(\mathrm{cm})$ was higher in treatment $\mathrm{T}_{1}$ in comparison with $T_{2}$. The higher length in common carp in $T_{1}$ and the lower length gain in rohu in $T_{1}$ was observed (Table 1). 
Table 1. Length gain performance (Mean $\pm S E$ ) of fish in polyculture ponds in $\operatorname{HSP}\left(T_{1}, n=5\right)$ and $\operatorname{MSP}\left(T_{2}, n=4\right)$

\begin{tabular}{l|c|r|r|r|r}
\hline Growth parameters & Treatments & \multicolumn{1}{c}{ Rohu } & \multicolumn{1}{c|}{ Catla } & Mrigal & Common carp \\
\hline Initial length (cm) & $\mathrm{T}_{1}$ & $6.06 \pm 0.00$ & $6.41 \pm 0.00$ & $6.20 \pm 0.00$ & $5.40 \pm 0.00$ \\
& $\mathrm{~T}_{2}$ & $6.06 \pm 0.00$ & $6.41 \pm 0.00$ & $6.20 \pm 0.00$ & $5.40 \pm 0.00$ \\
\hline Final length (cm) & $\mathrm{T}_{1}$ & $23.75 \pm 1.13$ & $28.47 \pm 2.50$ & $24.33 \pm 1.20$ & $37.00 \pm 0.00$ \\
& $\mathrm{~T}_{2}$ & $24.39 \pm 1.69$ & $27.18 \pm 2.40$ & $25.17 \pm 2.90$ & $23.75 \pm 4.25$ \\
\hline Length gain (cm) & $\mathrm{T}_{1}$ & $17.69 \pm 1.13$ & $22.06 \pm 2.50$ & $18.13 \pm 1.20$ & $31.60 \pm 0.00$ \\
& $\mathrm{~T}_{2}$ & $18.33 \pm 1.69$ & $20.77 \pm 2.40$ & $18.97 \pm 2.90$ & $18.35 \pm 4.25$ \\
\hline
\end{tabular}

\section{Weight gain (g)}

During the study period, weight gain was varied in different treatment. In treatment $T_{1}$, weight gain was higher compared to the treatment of $T_{2}$. Higher weight gain in $T_{2}$ was possibly due to moderately shaded ponds (Table 2). In terms of individual species, there were no significant differences $(p>0.05)$ of weight gain between two treatments (Table 2).

Table 2. Weight gain performance (Mean $\pm S E$ ) of fish in polyculture ponds in $\operatorname{HSP}\left(T_{1}, n=5\right)$ and $\operatorname{MSP}\left(T_{2}, n=4\right)$

\begin{tabular}{l|c|r|r|r|r}
\hline Growth parameters & Treatments & Rohu & Catla & Mrigal & Common carp \\
\hline Initial weight (g) & $\mathrm{T}_{1}$ & $2.37 \pm 0.00$ & $3.36 \pm 0.00$ & $2.54 \pm 0.00$ & $3.00 \pm 0.00$ \\
& $\mathrm{~T}_{2}$ & $2.37 \pm 0.00$ & $3.36 \pm 0.00$ & $2.54 \pm 0.00$ & $3.00 \pm 0.00$ \\
\hline Final weight (g) & $\mathrm{T}_{1}$ & $188.08 \pm 22.90$ & $373.43 \pm 122.30$ & $175.00 \pm 26.80$ & $470.00 \pm 0.00$ \\
& $\mathrm{~T}_{2}$ & $235.11 \pm 47.60$ & $409.58 \pm 140.80$ & $220.08 \pm 87.60$ & $390.40 \pm 160.40$ \\
\hline Weight gain (g) & $\mathrm{T}_{1}$ & $185.71 \pm 22.90$ & $370.07 \pm 122.30$ & $172.46 \pm 26.80$ & $467.00 \pm 0.00$ \\
& $\mathrm{~T}_{2}$ & $232.74 \pm 47.60$ & $406.22 \pm 140.80$ & $217.54 \pm 87.60$ & $387.40 \pm 160.40$ \\
\hline
\end{tabular}

\section{Growth performance of fishes}

Rohu and mrigal were stocked at 20 fingerlings where as catla and common carp were stocked in two treatments at the rate of 10 fingerlings per decimal. The average initial weight of rohu, catla, mrigal and common carp was $2.37 \pm 0.00 \mathrm{~g}, 3.36 \pm 0.00 \mathrm{~g}, 2.54 \pm 0.00 \mathrm{~g}, 3.00 \pm 0.00 \mathrm{~g}$, respectively in both $\mathrm{T}_{1}$ and $\mathrm{T}_{2}$. In MSP, the average final weight of rohu, catla, mrigal and common carp was $188.08 \pm 22.90 \mathrm{~g}$, $373.43 \pm 122.30 \mathrm{~g}, \quad 175.00 \pm 26.80 \mathrm{~g}, \quad 470.00 \pm 0.00 \mathrm{~g}$ and in HSP $235.11 \pm 47.60 \mathrm{~g}, 409.58 \pm 140.80 \mathrm{~g}$, $220.08 \pm 87.60 \mathrm{~g}$ and $390.40 \pm 160.40 \mathrm{~g}$, respectively.

\section{Total production}

The production of rohu, catla, mrigal and common carp ranged between $192.22 \pm 43$ to $744.95 \pm 111.20$ $\mathrm{kg} / \mathrm{ha} / \mathrm{year}$ in different treatments. The combined total production was higher in $\mathrm{T}_{2}(2122.92 \pm 333.60$ $\mathrm{kg} / \mathrm{ha} / \mathrm{year})$ and lower in $\mathrm{T}_{1}(1547.79 \pm 132.94 \mathrm{~kg} / \mathrm{ha} / \mathrm{year})$. As per analysis, the growth performance of each individual fish was not similar in two treatments (Fig. 2).

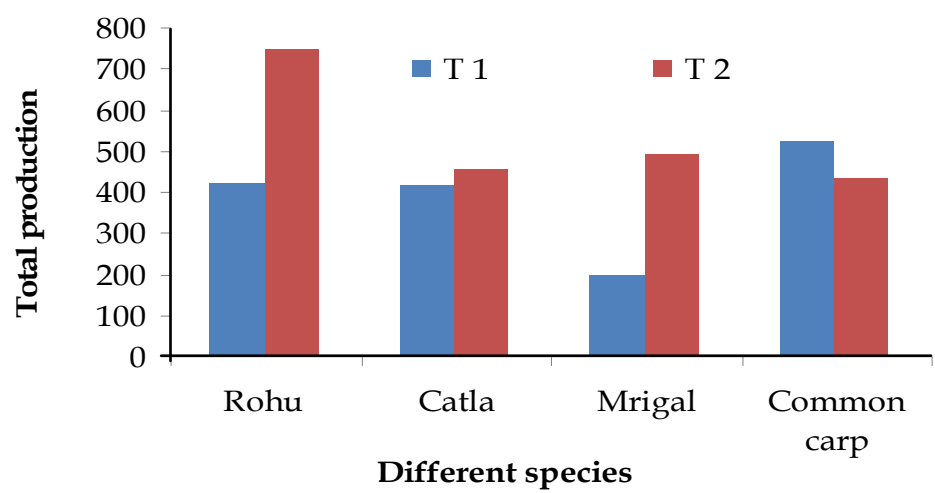

Fig. 2. Total production of individual fish in two treatments 


\section{Water quality parameters}

Aquaculture production depends on physical, chemical and biological qualities of pond water to a greater extend. The successful pond management requires an understanding of water quality. Intensification of pond makes the water quality undesirable with a number of water quality parameters. Pond water quality is largely defined by temperature, $\mathrm{pH}$, dissolved oxygen, nitrite and ammonia (Bhatnagar and Devi, 2013). Water quality parameters of the experimental ponds were recorded throughout the study period. In the present experiment, the mean values of water temperature was $22.60 \pm 0.40^{\circ} \mathrm{C}$ in $\mathrm{T}_{1}$ and $22.75 \pm 0.75^{\circ} \mathrm{C}$ in $\mathrm{T}_{2}$, the $\mathrm{pH}$ values was recorded $7.3 \pm 0.25$ in $\mathrm{T}_{1}$ and $7.4 \pm 0.43$ in $\mathrm{T}_{2}$. There were no major differences found in two treatments of the water quality parameters of $\mathrm{pH}$, dissolved oxygen, nitrite and ammonia (Table 3).

Table 3. Average (Mean \pm SE) value of water quality parameters of different treatments

\begin{tabular}{l|l|c|c|c|c}
\hline Treatments & Temperature $\left(^{\circ} \mathbf{C}\right)$ & $\begin{array}{c}\text { Dissolved } \\
\text { oxygen }(\mathbf{p p m})\end{array}$ & $\mathbf{p H}$ & Nitrite (ppm) & $\begin{array}{c}\text { Ammonia } \\
(\mathbf{p p m})\end{array}$ \\
\hline $\mathbf{T}_{\mathbf{1}}$ & $22.60 \pm 0.40$ & $4.20 \pm 0.49$ & $7.3 \pm 0.25$ & $0.10 \pm 0.03$ & $0.22 \pm 0.05$ \\
\hline $\mathbf{T}_{2}$ & $22.75 \pm 0.75$ & $4.75 \pm 0.85$ & $7.4 \pm 0.43$ & $0.08 \pm 0.03$ & $0.20 \pm 0.07$ \\
\hline
\end{tabular}

\section{Discussion}

In the present study, length gain was the higher in common carp $(31.60 \pm 0.00) \mathrm{cm}$ and lowest in rohu $(17.69 \pm 1.13) \mathrm{cm}$. Similarly the highest weight gain was found common carp $(467.00 \pm 0.00 \mathrm{~g})$ in $\mathrm{T}_{1}$ and lowest weight gained in mrigal $(172.46 \pm 26.80 \mathrm{~g})$ in $\mathrm{T}_{1}$. Every species in the two treatments, rohu, catla and mrigal gave the more or less similar length gain in $\mathrm{T}_{2}$ but common carp obtained the higher weight gain in $T_{1}$. Individual growth of rohu was found much higher in $T_{2}$ compared to $T_{1}$, probably due to the greater abundance of plankton in the $T_{2}$. It might be due to the availability of decomposing plant debris, insect larvae living in the mud (chironomids) etc. in the bottom region of pond which was used as feed by the common carp (Billard, 1995).

\section{Fish production}

The variation of production of fishes was found in two treatments. Between two treatments, the higher production of fish was recorded in $T_{2}$, followed by the production of $T_{1}$. The reason behind the higher production in treatment might be moderately shaded ponds (MSP). Kadir et al. (2006) obtained 1970 $\mathrm{kg} / \mathrm{ha}$ production in polyculture during 150 days culture period. Sagor (2008) obtained the average production of carp's $1676 \mathrm{~kg} / \mathrm{ha} / \mathrm{year}$. Haque (2010) reported good results from the polyculture of Indian carps in three treatments with the productivity ranging from $2618.85 \pm 57.5$ to $2747.47 \pm 116.47 \mathrm{~kg} / \mathrm{ha} / \mathrm{year}$. However, the fish productions recorded in the present study was $1547 \pm 132.94 \mathrm{~kg} / \mathrm{ha}$ and $2122 \pm 333.60$ $\mathrm{kg} / \mathrm{ha}$ in $T_{1}$ and $T_{2}$, respectively which was lesser than the study of Haque (2010). This was possibly due to following higher stocking density of carps in the study of Haque (2010) and the shaded nature of ponds. On the other hand individual production of common carp $(522.41 \pm 22.16 \mathrm{~kg} / \mathrm{ha})$ was higher in $\mathrm{T}_{1}$ because of the availability of decomposing plant debris, insect larvae living in the mud (chironomids) etc. in the heavily shaded pond bottom.

\section{Water quality parameters}

Aquaculture depends almost completely on the qualities of water, i.e. qualities of environment. Environment parameters exert in an important role on the growth, production of fish and other aquatic organisms. The suitable water quality parameters are prerequisite for a healthy aquatic environment and for the production of sufficient fish food organisms. Bhatnagar and Devi (2013) suggested that the desirable water temperature for carp polyculture in pond from 20 to $30^{\circ} \mathrm{C}$ which was more or less similar in the present study. They also reported that the desirable dissolved oxygen was $5 \mathrm{ppm}$ which was relevant in the present study and the dissolved oxygen content was recorded $4.20 \pm 0.49 \mathrm{ppm}$ in $\mathrm{T}_{1}$ and $4.75 \pm 0.85 \mathrm{ppm}$ in $\mathrm{T}_{2}$. The present findings agree with the findings of Ahmed (2004) who found that $\mathrm{pH}$ ranged from 6.6 to 8.9 in different treatments. For pond fish culture, the suitable ranges of $\mathrm{pH}$ are 6.5 to 8.5 (Byod, 2008). Stone and Thomforde (2004) suggested that the desirable range 0-1 ppm $\mathrm{NO}_{2}$ and 
acceptable range less than $4 \mathrm{ppm} \mathrm{NO}_{2}$. According to Bhatnagar et al. (2004) 0.02-1.0 ppm is lethal to many fish species, $>1.0 \mathrm{ppm}$ is lethal for many warm water fishes and $<0.02 \mathrm{ppm}$ is acceptable. Santhosh and Singh (2007) recommended nitrite concentration in water should not exceed $0.5 \mathrm{ppm}$. OATA (2008) recommended that it should not exceed $0.2 \mathrm{ppm}$ in freshwater fishes. So the results of the present study were more or less similar to that of the above author. Maximum limit of ammonia concentration for aquatic organisms is $0.1 \mathrm{ppm}$ (Santhosh and Singh, 2007). According to OATA (2008) the levels below $0.02 \mathrm{ppm}$ were considered safe. Bhatnagar and Singh (2010) recommended the level of ammonia $(<0.2 \mathrm{ppm})$ suitable for pond fishery. So, the result was safe for MSP but slightly harmful for HSP.

\section{Conclusion}

The shaded nature of ponds in Barisal region constrained the pond polyculture. However, there is a potential to practice carp polyculture which has been studied through the field experiment. From the above discussion, it was found that a higher level of individual fish growth was found for most carps in moderately shaded ponds (MSP), but common carp had higher growth in heavily shaded ponds (HSP). It could be argued that common carp was the most suitable species for polyculture in shaded ponds in Barisal region. This study was undertaken in a limited area of Barisal which does not represent the whole scenario of the shaded ponds of southern Bangladesh. Therefore, further studies need to be undertaken at different stocking density and species composition to explore ultimate potential of shaded ponds in that region for boosting up overall aquaculture production in Bangladesh.

\section{References}

Ahmed, H. 2004. Promotion of small Indigenous Fish Species (SIS) Mola based carp polyculture technology at Gazipur area of Bangladesh, MS Dissertation, Department of Fisheries Management, BAU, Mymensingh. pp. 85.

Bhatnagar, A. and Devi, P. 2013. Water quality guidelines for the management of pond fish culture. International Journal of Environmental Sciences 3(6) 1980-2009.

Bhatnagar, A., Jana, S.N. Garg, S.K. Patra, B.C. Singh, G. and Barman, U.K. 2004. Water quality management in aquaculture. In: Course Manual of summerschool on development of sustainable aquaculture technology in fresh and saline waters, CCS Haryana Agricultural, Hisar (India). pp. 203- 210.

Bhatnagar, A. and Singh, G. 2010. Culture fisheries in village ponds: a multi-location study in Haryana, India. Agriculture and Biology Journal of North America 1(5) 961-968.

Billard, R. 1995. Carp Biology and Culture (ed), INRA, Paris. pp. 322.

Boyd, C.E. 2008. Pond Bottom Soil Analyses, Translated from Global Aquaculture Advocate, 11:91-92, September-October 2008.

Dev, M. 2009. Polyculture of carps with tilapia, MS Thesis, Department of Aquaculture, Bangladesh Agricultural University, Mymensingh. pp. 25.

DoF. 2014. National Fish Week 2013 Compendium (in Bengali), Department of Fisheries, Ministry of Fisheries and Livestock, Bangladesh. pp. 144.

Halver, J.E.L. 1984. Special methods in pen fish husbandry. Akademiai Nyomda, Budapest. pp. 146.

Haque, M.M., Alam. M.R. Alam, M.M. Basak, B. Sumi, K.R. Belton, B. and Jahan, K.M.E. 2015. Integrated floating cage aquageoponics system (IFCAS): An innovation in fish and vegetable production for shaded ponds in Bangladesh. Aquaculture Reports 2 1-9.

Haque, R. 2010. Growth and production performance of carps in different stocking densities of polyculture, MS Thesis, Department of Aquaculture, Bangladesh Agricultural University, Mymensingh. pp. 35.

Kadir, A., Kundo, R.S. Milstein, A. and Wahab, M.A. 2006. Effects of silver carp and small indigenous species on the pond ecology and carp polyculture in Bangladesh. Aquaculture 261 1065-1076

OATA, 2008. Water Quality Criteria-ornamental fish. Company Limited by Guarantee and Registered in England No 2738119 Registered Office Wessex House, 40 Station Road, Westbury, Wiltshire, BA13 3JN, UK.

Rahman, M.M., Varga, I. and Chowdhury, S.N. 1992. Manual on Polyculture and Integrated Fish Farming in Bangladesh, Food and Agriculture Organization of the United Nations, Rome, Italy.

Rahman, M.M., Verdegem, M.C.J. Nagelkerke, L.A.J. Wahab, M.A. Milstein, A. and Verreth, J.A.J. 2006. Growth, production and food preference of Rohu Labeo rohita $(\mathrm{H}$.) in monoculture and in polyculture with Common carp Cyprinus carpio (L.) under fed and non-fed ponds. Aquaculture 257 359-372. 
Rumpa et al.

Sagor, M.F.H. 2008. Effects of different combinations of carp on pond ecology and fish production in carp Mola polyculture, MS Thesis, Department of Aquaculture, Bangladesh Agricultural University, Mymensingh.

Santhosh, B. Singh, P. 2007. Guidelines for water quality management for fish culture in Tripura, ICAR Research Complex for NEH Region, Tripura Center, Publication no.29.

Shepherd, Bromage, 1992. Intensive fish farming. Blackwell Scientific Publication, Oxford, Great Britain, U K, pp. 306-307.

Stone, N.M. Thomforde, H.K. 2004. Understanding Your Fish Pond Water Analysis Report, Cooperative Extension Program, University of Arkansas at Pine Bluff Aquaculture / Fisheries.

Tang, Y.A. 1970. Evaluation of balance between fishes and available fish ponds in multi species fish culture ponds in Taiwan. Trans Aqua Fish Soc. 99 708-712.

Wahab, M.A., Rahman, M.M. and Milstein, A. 2001. The effect on Common carp and Mrigal as bottom feeders in Indian carp polyculture. Aquaculture 32 50-52.

Wahab, M.A., Rahman, M.M. and Milstein, A. 2002. The effect of common carp (Cyprinus carpio) and Mrigal (Cirrhinus mrigala) as bottom feeders in Major Indian carp polycultures. Aquaculture Research 33 547-556. 